\title{
Intestinal Disaccharidase Deficiency in Children with Coeliac Disease
}

\author{
A. B. ARTHUR $\star$ \\ From the Department of Chemical Pathology, Institute of Child Health, and \\ The Hospital for Sick Children, Great Ormond Street, London, W.C.1
}

In a recent paper on their experiences with intestinal biopsy in children with coeliac disease, Sheldon and Tempany (1966) included evidence of a reduction in disaccharidase activity in many of the biopsies, thus confirming recently published observations (Plotkin and Isselbacher, 1964; Shmerling, Auricchio, Rubino, Hadorn, and Prader, 1964; Nordio, Lamedica, Vignolo, and Berio, 1965; Lifshitz, Klotz, and Holman, 1965).

In the present study certain aspects of the quantitative method of Plotkin and Isselbacher (1964) for estimation of disaccharidase activity have been investigated more fully. Disaccharidase activities were assayed, using a slight modification of their method, and histological examination of duodenal or jejunal mucosa was carried out in children who were suffering from coeliac disease (both treated and untreated) and they were compared with the findings in a group of children suffering from miscellaneous conditions resulting in malabsorption, and in a group with normal small intestinal mucosae.

Enzyme studies were also carried out in one case using necropsy material. The methods and results in this case are discussed separately.

\section{Material and Methods}

Coeliac disease: Studies were carried out on 12 children with coeliac disease aged 9 months to $10 \frac{1}{2}$ years. In each case the diagnosis of coeliac disease was confirmed by evidence of malabsorption, mucosal histology, and therapeutic response to a gluten-free dietary régime. Of these patients, 6 were new cases assessed before treatment, 3 had been on gluten-free diets for a variable period of time up to 2 years, 2 had relapsed following a return to normal diet, and 1 had been treated with a lactose-free diet for 8 months before the diagnosis of coeliac disease was made.

Received November 30, 1965.

^ Present address : Children's Department, St. Thomas' Hospital, London.
Miscellaneous malabsorption states: There were 4 patients with miscellaneous conditions: post-gastroenteric (2), steatorrhoea from exocrine pancreatic insufficiency (1), and glucose-galactose intolerance (1).

Normal mucosae: 6 patients, who were found after investigation to have normal or virtually normal (grade I) histology, served as normal controls.

Biopsy of distal duodenal or proximal jejunal mucosa was carried out in all 3 groups using a Crosby per-oral biopsy capsule. The specimens were examined under a dissecting microscope, and a portion was reserved for histological examination.

The remaining tissue was immediately rinsed in $0.85 \%$ saline and blotted dry to remove excess mucus, frozen on solid $\mathrm{CO}_{2}$, and stored at $-20^{\circ} \mathrm{C}$. until assayed. Assays were usually performed within 24-72 hours, though storage for at least two weeks was shown to have no deleterious effect on disaccharidase activities (see Table I).

\section{TABLE I}

Effect on Disaccharidase Activities of Storage at $-20^{\circ}$ C. (Necropsy Material)

\begin{tabular}{|c|c|c|c|c|}
\hline \multirow{2}{*}{$\begin{array}{l}\text { Period } \\
\text { of } \\
\text { Storage } \\
\text { (days) }\end{array}$} & \multicolumn{4}{|c|}{$\begin{array}{l}\text { Disaccharidase Activity } \\
\text { (units/g. mucosa, wet weight) }\end{array}$} \\
\hline & Lactase & Sucrase & Palatinase & Maltase \\
\hline $\begin{array}{c}2-7 \\
9-17 \\
37-39\end{array}$ & $\begin{array}{l}5 \cdot 51 \\
5 \cdot 42 \\
4 \cdot 85\end{array}$ & $\begin{array}{l}4 \cdot 93 \\
5 \cdot 99 \\
4 \cdot 95\end{array}$ & $\begin{array}{l}1 \cdot 37 \\
1 \cdot 52 \\
1 \cdot 40\end{array}$ & $\begin{array}{l}18 \cdot 50 \\
19 \cdot 57 \\
15 \cdot 84\end{array}$ \\
\hline
\end{tabular}

Figures represent means of triplicate assays from three sites, i.e. of 9 estimations.

Histology. Specimens were formalin-fixed, embedded in paraffin, sectioned, and stained with haematoxylin and eosin. Appearances under the dissecting microscope were correlated with the histological findings, all specimens being reviewed by Dr. C. L. Berry and graded according to the following criteria. 
TABLE II

Disaccharidase Activities and Mucosal Histology of Patients Studied

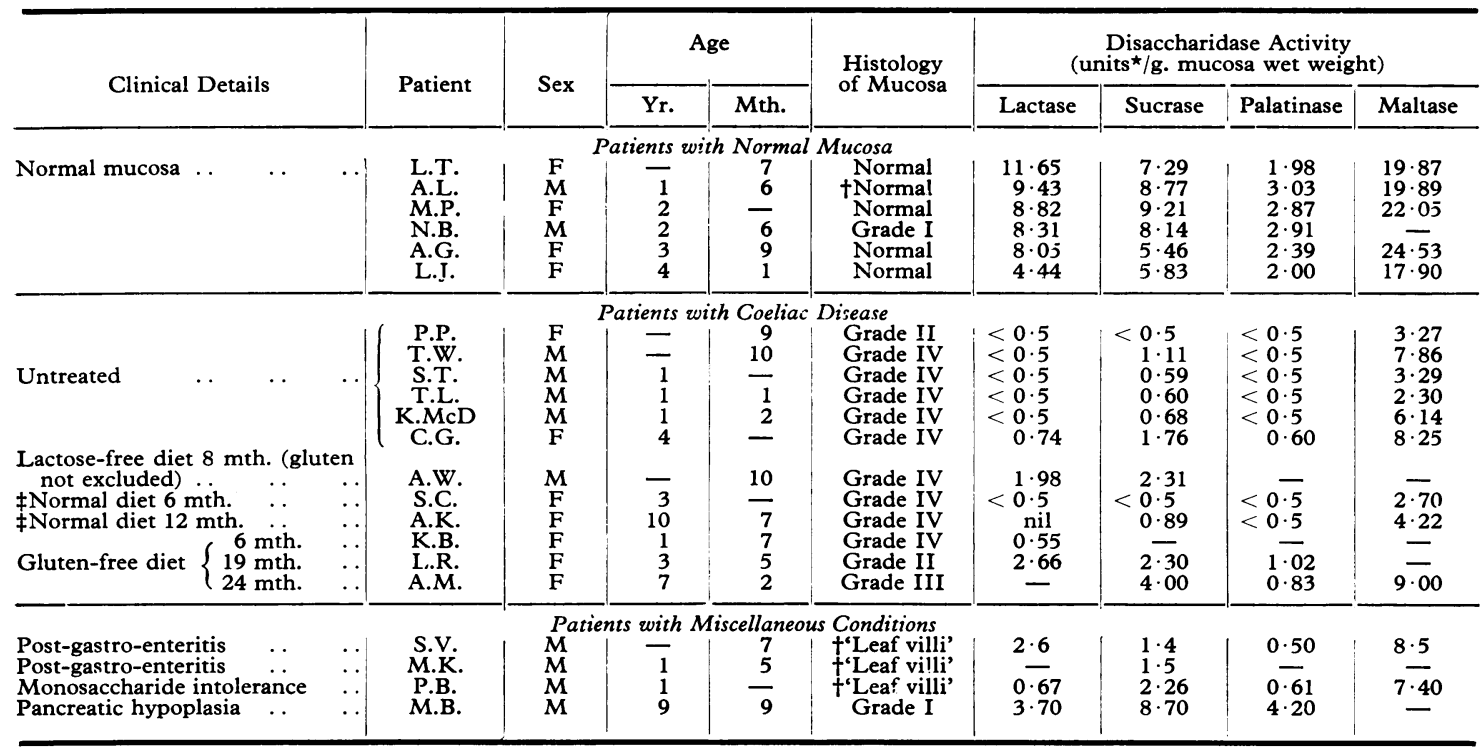

$\star$ Units $=\mu$ moles substrate hydrolysed per minute. † Appearance under dissecting microscope only. $¥$ Diet previously gluten-free. - Not estimated.

Normal: no abnormality detected by dissection microscopy or conventional histological methods.

Grade I: predominantly normal villous pattern on dissection microscopy; slight infiltration of the lamina propria with inflammatory cells seen histologically.

Grade II: thickened, leaf-like villi with some convoluted areas on dissection microscopy; heavy inflammatory cell infiltration of the lamina propria histologically, associated with shortened, oedematous villi.

Grade III: convoluted villous ridges on dissection microscopy; histological changes of partial villous atrophy.

Grade IV: 'flat' mucosa on dissection microscopy; histological changes of subtotal villous atrophy.

Disaccharidase activities. Lactase, sucrase (invertase), palatinase, and maltase were estimated after the method of Plotkin and Isselbacher (1964), with slight modification (as designed by Dr. A. D. Patrick). Sucrose, maltose (British Drug Houses Ltd., Poole), and palatinose (T. J. Sass and Sons Ltd., London), were prepared at concentrations of $0.056 \mathrm{M}$ in $0.1 \mathrm{M}$ maleate buffer $p H 6 \cdot 25$, lactose (Hopkin and Williams Ltd., Chadwell Heath) being prepared in similar concentration in $0.1 \mathrm{M}$ maleate buffer $\mathrm{pH} 5 \cdot 8$. Specimens of mucosa (usually $5-8 \mathrm{mg}$.) were homogenized in 49 volumes of ice-cold $0 \cdot 15 \mathrm{M} \mathrm{KC1}$. Mixtures containing $50 \mu \mathrm{l}$. homogenate $(12.5 \mu \mathrm{l}$. $+37.5 \mu \mathrm{l}$. water in the case of maltase) and $50 \mu \mathrm{l}$. disaccharide were incubated for 60 minutes at $37^{\circ} \mathrm{C}$., together with appropriate blanks, and after rapid dilution with $0.9 \mathrm{ml}$. water, the reaction was stopped by heating in a boiling-water bath for 4 minutes.
The liberated glucose was estimated with glucose oxidase ('Fermcozyme'-Hughes and Hughes Ltd. London), using TRIS-buffer (after Dahlqvist, 1961), it a total volume of $3 \mathrm{ml}$. After incubation for 30 minutes; $2 \mathrm{ml}$. concentrated $\mathrm{HCl}$ was added and extinctions were read at $530 \mathrm{~m} \mu$. on a 'Unicam SP 500 ' spectrophotometer. The $\mathrm{HCl}$ addition produces an optically stable red dye over a linear range of 5-60 $\mu \mathrm{g}$. glucose (A. E. Whitfield, 1965 , unpublished observations).

Disaccharidase activity was expressed in units ( $\mu$-moles of disaccharide hydrolysed per minute) per $\mathrm{g}$. wet weight of mucosa.

\section{Results}

Histology. The histological findings and the results of enzyme assays are shown in Table II.

In some cases inadequate material was available for histological sections, and the superficial appearance under the dissecting microscope alone was included. The majority of the untreated cases showed severe mucosal damage, with the exception of patient P.P.-the latter perhaps surprisingly in view of the severity of the disaccharidase deficiency. Severe lesions were seen in patients S.C. and A.K. following relapse on return to normal diet. The cases treated with gluten-free diets for 19 and 24 months, respectively, showed persistent mucosal abnormality, in keeping with the findings of Madanagopalan, Shiner, and Rowe (1965). Enzyme 
activity in the 2 patients with grade I mucosae appeared normal.

Disaccharidase activities. (1) Patients with coeliac disease. Results of assays in patients with coeliac disease are shown in Table II. Very low levels of disaccharidase activity (particularly affecting lactase) were seen in all untreated patients. In these, lactase activity ranged from $<0.5$ to 0.74 units $/ g$. (controls 4.44-11.65), sucrase from $<0.5$ to $1 \cdot 76$ units/g. (controls $5 \cdot 46-9 \cdot 21$ ), palatinase from $<0 \cdot 5$ to $0 \cdot 60$ units $/ \mathrm{g}$. (controls $1 \cdot 98-3 \cdot 03$ ), and maltase from $2 \cdot 30$ to $8 \cdot 25$ units/g. (controls $17 \cdot 90-24 \cdot 53$ ). The 3 treated cases showed increasing levels of activity, approximately in keeping with the duration of dietary exclusion of gluten.

The enzyme activities in the 2 patients (S.C. and A.K.), who, following clinical remission of symptoms on gluten-free diet, had reverted to a normal diet for periods of 6 and 12 months respectively, were at least as severely depressed as those in the untreated cases.

(2) Patients with miscellaneous malabsorption states. Two patients with recent histories of gastroenteritis showed decreased disaccharidase activities, with evidence of mucosal damage on dissection microscopy. An unusual feature of patient S.V., particularly as there had been some relief of symptoms with a low-lactose diet, was that the sucrase and palatinase activities were relatively more affected than that of lactase. In contrast with the report of Anderson, Kerry, and Townley (1965), the case of glucose-galactose intolerance (P.B.) showed decreased activities, especially of lactase, almost certainly explained by secondary mucosal damage during 10 months of severe intestinal symptoms before diagnosis. A further case (L.T.), of shorter duration, showed normal histology and is included among the controls. Case M.B., with steatorrhoea due to exocrine pancreatic insufficiency in association with neutropenia (Bodian, Sheldon, and Lightwood, 1964), showed normal enzyme activities, as would be anticipated.

(3) Children with normal mucosae. The enzyme activities in these 6 children were comparable with those previously observed in normal children (Burgess, Levin, Mahalanabis, and Tonge, 1964), and in normal adults (Dunphy, Littman, Hammond, Forstner, Dahlqvist, and Crane, 1965; Cuatrecasas, Lockwood, and Caldwell, 1965), as shown in Table III.

\section{Studies on Necropsy Material}

Specimens of tissue were obtained within two hours after death from a case of Wolman's disease. Approximately $2 \mathrm{~cm}$. segments of whole-thickness bowel wall were excised from the duodenum (3rd part), midjejunum, and mid-ileum, immediately frozen, and stored at $-20^{\circ} \mathrm{C}$. Mucosal scrapings were obtained as required, using a clean glass slide, and assayed as described above. Assays were performed in triplicate in an effort to ascertain the reproducibility of results, and were repeated at intervals up to 39 days after collection to determine the effect of prolonged storage on enzyme activity. A further aim of these studies was to compare the disaccharidase activities of the different sites along the small intestine. An analysis of variance was performed to investigate the differences between sites, and the effect of duration of storage (Appendix). In view of the time lapsing between death and the collection of specimens, and of the lethal nature of the disease, recorded activities have no absolute meaning but the comparative values are considered valid.

\section{Results}

Localization of enzyme activity. Each disaccharidase was shown to be widely distributed throughout the small intestine, the highest activities, except for maltase, being found in the mid-jejunum (Table IV). Lactase activity was significantly greater at mid-jejunum than at 3rd part of the duodenum ( $\mathrm{p}<0.001$ ) or mid-ileum ( $\mathrm{p}<0.001$ ), duodenal activity being significantly greater than ileal $(\mathrm{p}<0.001)$. Sucrase activity was also

TABLE III

Disaccharidase Activities in Normal Patients

\begin{tabular}{|c|c|c|c|c|c|c|}
\hline \multirow{2}{*}{\multicolumn{3}{|c|}{ Series }} & \multicolumn{4}{|c|}{ Disaccharidase Activity ( ${ }^{\star}$ units/g. mucosa, wet weight) } \\
\hline & & & Lactase & Sucrase & Palatinase & Maltase \\
\hline $\begin{array}{l}\text { Burgess et al. }(1964) \\
\text { Children-5 cases } \\
\text { Dunphy } \text { et al. }(1965) \\
\text { Adults-22 cases } \\
\text { Cuatrecasas } \text { et al. }(1965) \dagger \\
\text { Adults-7 cases } \\
\text { Present series } \\
\text { Children-6 cases }\end{array}$ & $\begin{array}{l}\cdots \\
\cdots \\
\cdots \\
\cdots\end{array}$ & $\begin{array}{l}\cdots \\
\cdots \\
\cdots\end{array}$ & $\begin{array}{c}8 \cdot 7 \\
(6 \cdot 6-12 \cdot 4) \\
4 \cdot 73 \\
(1 \cdot 0-7 \cdot 8) \\
2 \cdot 65 \\
(1 \cdot 67-4 \cdot 20) \\
8 \cdot 45 \\
(4 \cdot 44-11 \cdot 65)\end{array}$ & $\begin{array}{c}17 \cdot 4 \\
(12 \cdot 4-20 \cdot 2) \\
9 \cdot 77 \\
(2 \cdot 94-16 \cdot 4) \\
9 \cdot 29 \\
(5 \cdot 65-13 \cdot 58) \\
7 \cdot 45 \\
(5 \cdot 46-9 \cdot 21)\end{array}$ & 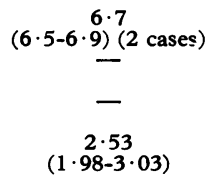 & $\begin{array}{c}62 \cdot 6 \\
(43 \cdot 2-88 \cdot 9) \\
29 \cdot 68 \\
(11 \cdot 2-50 \cdot 5) \\
28 \cdot 08 \\
(15 \cdot 74-45 \cdot 6) \\
20 \cdot 85 \\
(17 \cdot 90-24 \cdot 53)\end{array}$ \\
\hline
\end{tabular}

$\star$ Units $=\mu$ moles of substrate hydrolysed per minute. † Converted from dry weight $(=17 \cdot 2 \%$ of wet weight-author's figures). 
maximal at mid-jejunum, being significantly greater than duodenal activity ( $p<0.001)$, the difference between duodenum and ileum not being significant. Maltase activity was maximal in mid-ileal samples, being significantly greater than mid-jejunum $(p<$ $0.001)$, which in turn was significantly greater $(\mathrm{p}<$ 0.001 ) than 3 rd part of duodenum. Differences in distribution of palatinase activity were not significant. These studies suggest that the exact site of a mucosal biopsy is not of great practical significance in regard to disaccharidase estimations, particularly as there was virtually no overlap between normal and abnormal values in the clinical studies. It is emphasized, however, that these findings concern material from one case only.

\section{TABLE IV}

\section{Localization of Disaccharidase Activities} (Necropsy Material)

\begin{tabular}{|c|c|c|c|c|}
\hline \multirow{2}{*}{$\begin{array}{l}\text { Site of } \\
\text { Specimen }\end{array}$} & \multicolumn{4}{|c|}{$\begin{array}{c}\text { Disaccharidase Activity } \\
\text { (units/g. mucosa, wet weight) }\end{array}$} \\
\hline & Lactase & Sucrase & Palatinase & Maltase \\
\hline $\begin{array}{lll}\text { Duodenum (3rd part) } & \ldots \\
\text { Mid-jejunum } & \ldots & \ldots \\
\text { Mid-ileum } & \ldots & \ldots\end{array}$ & $\begin{array}{l}5 \cdot 52 \\
5 \cdot 85 \\
4 \cdot 48\end{array}$ & $\begin{array}{l}5 \cdot 02 \\
5 \cdot 56 \\
5 \cdot 36\end{array}$ & $\begin{array}{l}1 \cdot 44 \\
1 \cdot 52 \\
1 \cdot 34\end{array}$ & $\begin{array}{l}15 \cdot 85 \\
18 \cdot 65 \\
19 \cdot 43\end{array}$ \\
\hline
\end{tabular}

Figures represent means of triplicate assays carried out on 3 occasions, i.e. of 9 estimations.

Effect of storage. There was some decrease in activity by the sixth week of storage at $-20^{\circ} \mathrm{C}$. (Table IV), probably accentuated by thawing and refreezing to obtain successive samples. Loss of activity appeared considerable for lactase and maltase and negligible for sucrase and palatinase: variable durations of storage before assay made the results unsuitable for formal statistical analysis. Activities after storage for two weeks were unimpaired.

Reproducibility of results. Analysis of the results of assays performed in triplicate on the same homogenate showed the coefficient of variation (standard error expressed as a percentage of the mean) to be $\pm 2 \cdot 64 \%$ for lactase, $\pm 3 \cdot 48 \%$ for sucrase, $\pm 5 \cdot 47 \%$ for palatinase, and $\pm 1 \cdot 36 \%$ for maltase, i.e. reproducibility of results was good. Greater variation was found between assays of adjacent samples of tissue, partly explained by inevitable variation in the depth of the mucosal scrapings, further sources of possible error being in the weighing and dilution of samples before homogenization.

\section{Discussion}

Coeliac disease was described by Gee in 1888 , yet over 60 years elapsed before the vital role of the gluten fraction of wheat flour in the aetiology of a hitherto puzzling disease was recognized (Dicke, 1950). Despite this major advance, difficulty was experienced in many cases in successfully establishing severely affected children on a gluten-free diet, the initial clinical response to exclusion of gluten often being disappointing (Sheldon, 1959). A possible explanation, i.e. associated intolerance to disaccharides, was suggested by the demonstration that diarrhoea could be caused by deficiency of sugar-splitting enzymes (Weijers, Van de Kamer, Dicke, and Ijsseling, 1961), and by the demonstration in coeliac patients of intolerance to milk (Cooke, Fone, Cox, Maynell, and Gaddie, 1963), and to sucrose (Sheehy and Flock, 1964).

Histological studies have shown that in coeliac disease the characteristic pathological feature is mucosal flattening with villous atrophy, principally affecting the proximal small intestine (Shiner and Doniach, 1960). Demonstrated initially in adults (Paulley, 1954), this was first confirmed in children by Sakula and Shiner (1957). Once thought to be a finding specific to coeliac disease, it is now shown to be found in a variety of disorders (Hindle and Creamer, 1965).

Disaccharide hydrolysis is a specific enzymatic function, the disaccharidases being located in the vicinity of the brush-border of the intestinal mucosal epithelium (Miller and Crane, 1961). Some contention exists regarding the exact distribution of the different disaccharidases along the intestinal tract, but both disaccharidase activity (Auricchio, Rubino, Tosi, Semenza, Landolt, Kistler, and Prader, 1963) and disaccharide absorption (Dahlqvist and Borgström, 1961; Gray and Inglefinger, 1965) appear to be maximal in the jejunum, i.e. in the region of maximal mucosal damage in coeliac disease.

Recent work (Plotkin and Isselbacher, 1964; Shmerling et al., 1964; Nordio et al., 1965; Sheldon and Tempany, 1966) has clearly demonstrated decreased activities of mucosal disaccharidases in untreated patients with coeliac disease, and the return towards more normal values associated with mucosal regeneration in response to dietary treatment, thus providing a convincing explanation for the disaccharide intolerance often accompanying acute coeliac disease. The present investigation, on a further 12 patients, confirms these findings. Lactase activity was most affected, and was slowest to return toward normal values in response to treatment with a strict gluten-free diet. Shmerling et al. 
(1964), reporting on biopsies from 13 children, showed that the activity of sucrase, isomaltase, and maltase increased in parallel with the clinical improvement, but that lactase activity remained selectively depressed in about half the cases subjected to serial biopsy. Lifshitz et al. (1965) have recently shown that lactose intolerance, as manifested by a poor glycaemic response to oral lactose loading and production of symptoms such as diarrhoea and abdominal cramps, was present in 4 out of 6 patients with coeliac disease, and that lactase activity in mucosal biopsy specimens was absent (as estimated chromatographically) in all patients before treatment. Rapid clinical improvement followed exclusion of lactose from the diet of those previously showing poor response to a gluten-free régime, though lactase activity returned to normal in only one patient after the start of dietary treatment.

The studies on necropsy material showed that the method used for estimation of disaccharidase activity gave consistent results within reasonable limits of accuracy, the coefficient of variation for triplicate assays performed on the same homogenate ranging from $\pm 1 \cdot 36 \%$ for maltase to $\pm 5 \cdot 47 \%$ for palatinase.

Complete assays were readily determined on 5-8 $\mathrm{mg}$. wet weight of mucosa, and satisfactory use of smaller samples could also be made by minimizing the number of blank estimations.

Studies on the distribution of activity within the small intestine were in agreement with those of Auricchio et al. (1963), in that maximal activity was demonstrated in the jejunum, but indicated that enzyme activity was widely distributed. Determination of the precise site of a per-oral biopsy is difficult, and these studies suggest that the exact localization of a biopsy specimen does not have great practical importance in regard to disaccharidase estimation.

\section{Summary}

The disaccharidase activities of the mucosa of the small intestine of 12 patients with coeliac disease are reported, comparison being made with 6 normal subjects.

Disaccharidase activity was greatly diminished in untreated patients, lactase being the most severely affected; a slow return of activity, accompanying mucosal regeneration, was seen following treatment with a gluten-free diet. These findings are in agreement with the recently published reports of other workers.

Biopsy specimens could be stored at $-20^{\circ} \mathrm{C}$. for at least two weeks without loss of activity, and the quantitative method employed gave reproducible results on 5-6 mg. samples of material.
I thank the physicians of this hospital, particularly Sir Wilfrid Sheldon and Dr. D. G. Cottom, for permission to study their cases; Dr. C. L. Berry who reviewed the histological sections; and Dr. Barbara E. Clayton and Dr. A. D. Patrick for their helpful advice and criticism throughout.

I am indebted to the Nuffield Foundation for financial assistance with this project, which was associated with a survey of mental abnormalities in children.

\section{REFERENCES}

Anderson, C. M., Kerry, K. R., and Townley, R. R. W. (1965). An inborn defect of intestinal absorption of certain monosaccharides. Arch. Dis. Childh., 40, 1.

Auricchio, S., Rubino, A., Tosi, R., Semenza, G., Landolt, M., Kistler, H., and Prader, A. (1963). Disaccharidase activities in human intestinal mucosa. Enzymol. Biol. Clin. (Basel), 3, 193.

Bodian, M., Sheldon, W., and Lightwood, R. (1964). Congenital hypoplasia of the exocrine pancreas. Acta paediat. (Uppsala), 53, 282.

Burgess, E. A., Levin, B., Mahalanabis, D., and Tonge, R. E. (1964). Hereditory sucrose intolerance: levels of sucrase activity in jejunal mucosa. Arch. Dis. Childh., 39, 431.

Cooke, W. T., Fone, D. J., Cox, E. V., Maynell, M. J., and Gaddie, R. (1963). Adult coeliac disease. Gut, 4, 279.

Cuatrecasas, P., Lockwood, D. H., and Caldwell, J. R. (1965). Lactase deficiency in the adult. A common occurrence. Lancet, 1, 14.

Dahlqvist, A. (1961). Determination of maltase and isomaltase activities with a glucose-oxidase reagent. Biochem. $\mathcal{F} ., 80,547$.

$\longrightarrow$, and Borgström, B. (1961). Digestion and absorption of disaccharides in man. ibid., 81, 411.

Dicke, W. J. (1950). Coeliac disease: a study of the damaging effects of some cereals, especially wheat, caused by a factor outside of their starch, on the fat absorption of children with coeliac disease. Trans. 6th Int. Congr. Paediat., Zürich, 1950, p. 117.

Dunphy, J. V., Littman, A., Hammond, J. B., Forstner, G., Dahlqvist, A., and Crane, R. K. (1965). Intestinal lactase deficit in adults. Gastroenterology, 49, 12.

Gabriel, K. R. (1964). A procedure for testing the homogeneity of all sets of means in analysis of variance. Biometrics, 20, 459.

Gee, S. (1888). On the coeliac affection. St Bart. Hosp. Rep., 24, 17.

Gray, G. M., and Ingelfinger, F. J. (1965). Intestinal absorption of sucrose in man: the site of hydrolysis and absorption. $\mathcal{f}$. clin. Invest., 44, 390.

Hindle, W., and Creamer, B. (1965). Significance of a flat smallintestinal mucosa. Brit. med. $\mathcal{Y}$., $2,455$.

Lifshitz, F., Klotz, A. P., and Holman, G. H. (1965). Intestinal disaccharidase deficiencies in gluten-sensitive enteropathy. Amer. F. dig. Dis., 10, 47.

Madanagopalan, N., Shiner, M., and Rowe, B. (1965). Measurements of small intestinal mucosa obtained by peroral biopsy. Amer. F. Med., 38, 42.

Miller, D., and Crane R. K. (1961). The digestive function of the epithelium of the small intestine. II. Localization of disaccharide hydrolysis in the isolated brush border portion of intestinal epithelial cells. Biochim. biophys. Acta (Amst.), 52, 293.

Nordio, S., Lamedica, G. M., Vignolo, L., and Berio, A. (1965). Six cases of lactose intolerance. Ann. paediat. (Basel), 204, 3.

Paulley, J. W. (1954). Observations on the aetiology of idiopathic steatorrhoea: Jejunal and lymph-node biopsies. Brit. med. F., 2, 1318.

Plotkin, G. R., and Isselbacher, K. J. (1964). Secondary disaccharidase deficiency in adult celiac disease (non-tropical sprue) and other malabsorption states. New Engl. F. Med., 271, 1033.

Sakula, J., and Shiner, M. (1957). Coeliac disease with atrophy of the small-intestine mucosa. Lancet, 2, 876.

Sheehy, T. W., and Flock, M. H. (1964). The Small Intestine. Harper and Row, New York.

Sheldon, W. (1959). Celiac disease. Pediatrics, 23, 132. , and Tempany, E. (1966). Small intestine per-oral biopsy in coeljac children. Gut. In the press.

Shiner, M., and Doniach, I. (1960). Histopathologic studies in steatorrhea. Gastroenterology, 38, 419. 
Shmerling, D, H., Auricchio, S., Rubino, A., Hadorn, B., and Prader, A. (1964). Der sekundäre Mangel an intestinaler Disaccharidaseaktivität bei der Cöliakie. Helv. paediat. Acta, $19,507$.

Weijers, H. A., Van de Kamer, J. H., Dicke, W. K., and Ijsseling, J. (1961). Diarrhoea caused by deficiency of sugar splitting enzymes. I. Acta paediat. (Uppsala), 50, 55.

\section{Appendix}

Statistical Analysis. The design of the experiment was a nested one, and a paremetric model for the analysis of variance was assumed.

An analysis of variance (see Table below) was performed to investigate differences between sites, and differences due to time of storage. Since pairwise comparisons of sites were also of interest, the three comparisons of each site with every other site were made, in such a way as to keep the significance level of the over-all test of difference among the three sites at not more than 5\% (see, for example, Gabriel, 1964).

Analysis of Variance Table

\begin{tabular}{|c|c|c|c|c|c|c|}
\hline & & & Source & Sum of Squares & Degrees of Freedom & Mean Squares \\
\hline Lactase & $\cdots$ & . & $\begin{array}{l}\text { Times } \\
\text { Sites } \\
\text { Residual } \\
\text { Total }\end{array}$ & $\begin{array}{r}8.9797 \\
11.0527 \\
0.9871 \\
21.0195\end{array}$ & $\begin{array}{r}6 \\
2 \\
17\end{array}$ & $\begin{array}{l}1.4966 \\
5.5264 \\
0.0581\end{array}$ \\
\hline Sucrase & $\cdots$ & .. & $\begin{array}{l}\text { Times } \\
\text { Sites } \\
\text { Residual } \\
\text { Total }\end{array}$ & $\begin{array}{r}10 \cdot 7437 \\
1 \cdot 2713 \\
1 \cdot 7350 \\
13 \cdot 7500\end{array}$ & $\begin{array}{r}6 \\
2 \\
17\end{array}$ & $\begin{array}{l}1 \cdot 7906 \\
0.6357 \\
0 \cdot 1021\end{array}$ \\
\hline Palatinase & . & . $\quad .$. & $\begin{array}{l}\text { Times } \\
\text { Sites } \\
\text { Residual } \\
\text { Total }\end{array}$ & $\begin{array}{l}0.2222 \\
0 \cdot 1336 \\
0.3153 \\
0 \cdot 6711\end{array}$ & $\begin{array}{r}6 \\
2 \\
17\end{array}$ & $\begin{array}{l}0.0370 \\
0.0668 \\
0.0185\end{array}$ \\
\hline Maltase & . & $\begin{array}{ll}. & . .\end{array}$ & $\begin{array}{l}\text { Times } \\
\text { Sites } \\
\text { Residual } \\
\text { Total }\end{array}$ & $\begin{array}{r}148 \cdot 4796 \\
63 \cdot 7230 \\
3 \cdot 1328 \\
215 \cdot 3354\end{array}$ & $\begin{array}{r}6 \\
2 \\
17\end{array}$ & $\begin{array}{r}24 \cdot 7466 \\
31 \cdot 8615 \\
0.1843\end{array}$ \\
\hline
\end{tabular}

